\title{
REPUTATIONAL RISK MANAGEMENT
}

\author{
Jan Krzysztof Solarz* ${ }^{*}$ http://orcid.org/0000-0001-6528-7645
}

\begin{abstract}
Background. Reputational risk cross building competitive position or mark management. Shareholders of reputational risk management are more heterogenic. Therefore, it is not surprising that managing reputational risk has now become a major preoccupation for business in the private, public and not-for profits sectors.

Research aims. The reputational risk is placed at the top of the risk hierarchy as the risk of others risks. As such, it need in new cognitive framework. In this case we study how manage complexity item.

Methodology. Comparative analysis of models of reputation risk management devoted the cognitive framework located in time and institutional space.

Key findings. Reputational risk management is reduction of internal cost of particular activity, cover transactional cost of monitoring such type of risk and calculate external cost of reputation lost. One of this external cost is crush of reputation on public trust institutions. The current paper demonstrates and reviews different theoretical perspectives that conceptualize reputational risk management. The first part presents cognitive perspective on reputation. The second part covers behavioral approach to risk management. Finally, the paper provides practitioners with a systematic review of different approaches adopted to study reputational risk management.
\end{abstract}

Keywords: reputational risk, moral hazard, cognitive framework.

JEL Codes: A14, H12, P50

\section{INTRODUCTION}

The reputational risk is placed at the top of the risk hierarchy as the risk of other risks. Without reputation, it is impossible to function in an electronic economy and to provide services at a distance (Gospodarowicz, 2018).

\footnotetext{
Institut of Economics, University of Social Science, Łucka 11, Warszawa 05-077, Poland. E-mail: jksolarz@san.edu.pl
} 
With universal agreement on the importance of reputation in modern economy and society, there is no universally accepted definition of 'reputation' and the essence of 'reputational risk'. Therefore, the first point of the study is devoted to the cognitive framework of reputation located in time and institutional space. The author took the position that reputation is behavior from the past that leaves an electronic footprint and generates internal costs. Reputation is often confused with moral hazard and personal, institutional and cultural trust. Thus, one can speak of a comprehensive understanding of reputation as a factor reducing all kinds of costs of social and economic interactions.

The second point of the study reminds the stages of risk management. It begins with identifying the risk. Still many researchers believe that there is no such thing as a reputational risk. Cognitively, they are right, because we are sure that unworthy deeds have been committed in the past. The risk arises when this type of reprehensible behavior is revealed today, the image will be lost. The possibility of leaving unworthy facts from the past in the future creates an atmosphere of uncertainty and distrust.

Some see the risk of loss of reputation as a manifestation of the occurrence of operational risk. Professional risk management can start with risk measurement. The sums of penalties imposed on car companies for falsifying actual gas emissions and on banks for unfair sales practices make the market participants aware of the scale of reputational risk.

When there is no risk of reputational damage, there is no doubt about managing it. Some put emphasis on prevention and prefer insurance. Others calculate the scale of specific provisions for this purpose. Most try to disperse the risk of losses among stakeholders interested in rebuilding the good reputation of the organization. Few sell this risk to specialized institutions, rating agencies, internet portals, social media and consumer protection authorities. It happens that the attack is considered the best defense and it is indicated that reputational defects are more common than it is believed. Management by means of shocks makes it possible to consider acts that used to bring shame as a norm.

The third section of the paper presents practical models of reputational risk management from the most elementary and one-stage to the most complex and dynamic. In total, the study aims to point to 
a white spot in the theory and practice of risk management. It deals with reputational risk management.

\section{A COGNITIVE FRAMEWORK OF REPUTATION}

'Reputation is what is generally said or believed about a person's or thing's character or standing' (Joesang et al., 2007, p. 623). Reputation can be treated as an intangible asset and as a component of liabilities-buffer against losses. Loss is seen as a signal that the organization has a poor control environment. Reputational risk can therefore be defined as 'the risk of an economic loss associated with a negative reception of the organization by customers, supervisors, regulators and the public, or as a risk of goodwill impairment not related to impairment of accounting, usually reflected in a drop in its stock value' (Miklaszewska, 2018, p. 105).

As the table 1 shows, reputation is based on aggregate past experience, the moral hazard concerns the present game of interests, and trust is directed towards the future, it is a kind of a bid how the organization will behave in conditions of uncertainty.

Table 1. Conceptual framework for reputation analysis

\begin{tabular}{|l|c|c|c|}
\hline \multicolumn{1}{|c|}{ Dimensions } & Internal costs & Transactional costs & External costs \\
\hline Past (certainty) & Reputation & & \\
\hline Present (risk) & & $\begin{array}{c}\text { Moral hazard, } \\
\text { conflict of interests }\end{array}$ & \\
\hline Future (uncertainty) & & & Trust \\
\hline
\end{tabular}

Source: author's own elaboration.

Assigning the reputation to the past must be objectionable. Reputation reduces uncertainty and therefore has implications for the future. It is an informal market regulator. Fear of deterioration leads to behaviors in line with social expectations. The difference between the reputation and the image is then blurred.

It can therefore be argued that:

1. Reputation is based on a coherent pattern of a business entity's activities in the past, formed under the influence of its identity, these are certain facts from the past. 
2. The appointment is external to the economic entity and remains outside its control, but it may affect it, influencing its shaping factors. It is the risk that some facts will come to the attention of stakeholders.

3. Social responsibility has a positive impact on the reputation of the business entity and allows rationalization of the approach to reputational risk. We are still confronted with uncertainty whether unfavorable facts from the past will come to the surface of events.

4. Trends occurring in the environment of modern business entities increase the importance of reputation and lead to an increase in the level of reputation risk (Dabrowski, 2016, p. 12).

A good reputation increases the rate of return on assets, but it does not guarantee a sufficiently rapid growth of the family business. Its founders choose either maintaining a good reputation and free, organic growth of the company or a rapid growth of the company thanks to its external financing in the loss of reputation related to the name of the company's founder. In practice, successors choose rapid growth of the company at the expense of losing their previous reputation. This temptation of abuse against the founder of the business is common (Belenzon et al., 2018).

The moral hazard is a situation in which the decision maker assesses the appetite for risk, and the stakeholder bears the cost that it will materialize. This is not a one-off decision-making situation, but a certain decision-making structure that has durability features. In financial jargon, it is the size of the financial leverage (Berent, 2013).

Electronic platforms increase the transparency of markets and thus limit the moral hazard. The real-time assessment of sellers and buyers as well as price competition allows counteracting the increase of external costs of the services provided (Liu et al., 2018).

Transfer of risk, which takes place with the consent of the parties to the transaction, does not bear the moral hazard. The hazard arises when profits are privatized and losses are nationalized. This conflict of interest is particularly evident in the conditions of the free movement of capital, then market participants are subjected to blackmail for immediate withdrawal of capital from the country that does not have a good investment climate. Then a vicious circle of moral hazard arises (Figure 1). 


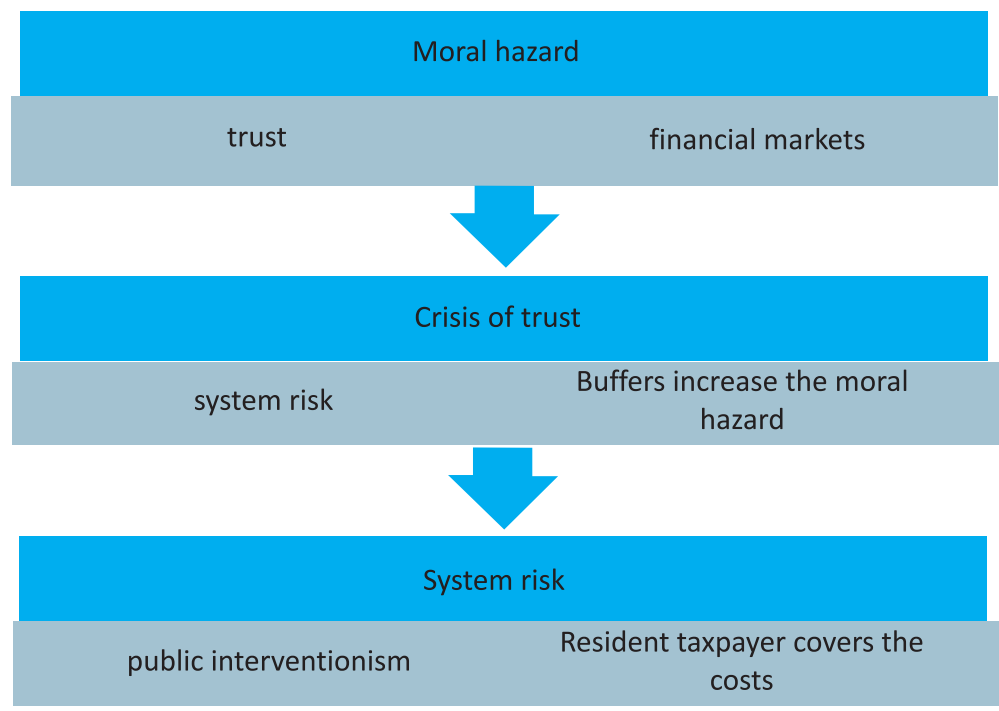

Figure 1. Vicious circle of moral hazard

Source: author's elaboration on the basis of: Pawłowicz, 2018, pp. 55-69.

The key variable of the presented scheme of explaining the impact of the variable over time is the crisis of trust. However, it is necessary to specify what is meant by trust here. The literature on the subject speaks about three types of trust: interpersonal, in a specific other person, institutional trust, for example, in an institution of public trust, and the widest trust in political parties or one's own culture and identity.

Trust is the belief that the other side:

- will not act against us,

- will work in a way that is beneficial to us,

- will be reliable,

- will behave in a predictable manner and comply with generally accepted standards (Paliszkiewicz, 2013, p. 23).

For the economic development of the country, trust in public institutions is of the greatest importance. In 46 countries surveyed, it turned out that the reputation of property rights and the judicial system is decisive for shaping the general trust of the population (Hwang, 2017).

At this point, considerations must be made to distinguish between reputation and trust. In both cases, we have asymmetry, between their 
acquisition and loss. Trust cannot be restored only by increasing the transparency of behavior. Reputation is built on the basis of information asymmetry. Public information builds an image that is sold to stakeholders. Private information describes a substantial reputation. The more these two sources of information diverge, the greater the risk of reputation damage (Thakor \& Merton, 2018).

The asymmetry between reputation and trust is most fully expressed by costs. In the case of reputation, these are internal costs that arise when you make such and such decision. Its consequences in time will last in the full life cycle of a given product or service. When buying a printer, we forget about the costs of its operation. Only when we look at the purchase from the perspective of its entire life we know what internal costs we are being exposed to.

Each of our actions on the Internet leaves an electronic trace. If our behavior is morally reprehensible, it entails consequences which are revealed after many years. We will be punished for breaking consumer rights or unethical competition. We will not avoid internal costs with a clever advertising campaign or professional crisis management.

In the case of trust, there are external costs incurred by third parties towards our original bid to protect one or another person in the future. Confidence is the nucleus of social capital (Fukuyama, 1997).

Lack of control of external costs of decisions leads to moral hazard, forcing temporary benefits, at the expense of long-term losses. Rational recognition of transaction costs in full contracts creates conditions for the correct calculation of costs and a transparent price structure.

Summing up, reputation can be treated as an invisible resource of the organization, a key factor for its success, an element of responsible development of the industry, an important element of the decisions made (Dylag \& Jedynak, 2016).

\section{RISK MANAGEMENT}

Risk management has evolved from art to the standard. As a consequence, there is a situation in which:

- there is a large variety of risk definitions,

- $\quad$ some definitions coexist relatively universally and others have a more specific and detailed form (Jedynak, 2018, p. 11) (Figure 2). 


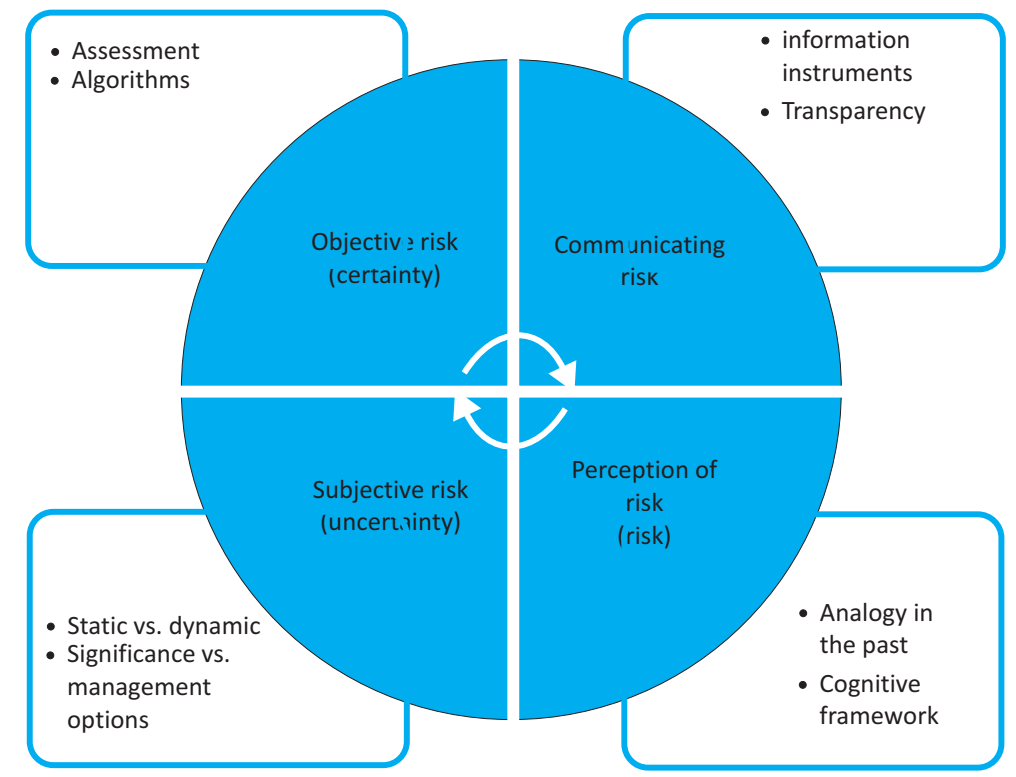

Figure 2. Risk management perspectives

Source: Linciano \& Soccorso, 2017, p. 56.

The issue of the quality of risk management has been at the center of attention of decision-makers for at least ten years. BP lost its reputation in the Gulf of Mexico, Volkswagen in falsifying emissions results. Warren Buffet warned that it takes twenty years to build a positive reputation but five minutes to lose it. One should not be mistaken that in this case it will be different.

Enron and WorldCom scandals show that reputation is lost in real time. Reputation is identified with the company's brand, its recognition. Experience with a given brand raises expectations. If they coincide with these expectations then we talk about good reputation.

Good reputation affects:

- shareholders' decisions to retain shares,

- tendency of consumers to purchase products and services of a given company,

- readiness of suppliers to maintain contacts,

- readiness of competitors to enter the market occupied by the company,

- media image,

- NOG and lobbying groups activity, 
- relationship between supervisory and regulatory authorities,

- costs of capital acquisition,

- acquiring talented staff,

- motivation to work in a given company,

- resistance to external shocks.

Reputational risk management requires a break from the golden management pattern and the adoption of a situational perspective. The methods of managing this type of risk directly depend on the stage of development of a given economic entity. Table 2 shows the dependence of the selection of management methods on the characteristics of the management object.

Table 2. Institutional perspective on risk management

\begin{tabular}{|l|c|c|c|c|}
\hline \multicolumn{1}{|c|}{$\begin{array}{c}\text { Stages / } \\
\text { forms }\end{array}$} & $\begin{array}{c}\text { Risk } \\
\text { identification }\end{array}$ & $\begin{array}{c}\text { Risk } \\
\text { assessment }\end{array}$ & Risk trade & $\begin{array}{c}\text { Shock } \\
\text { management }\end{array}$ \\
\hline Organizations & internal costs & & & \\
\hline Systems & & transacional cost & & \\
\hline Networks & & & $\begin{array}{c}\text { external } \\
\text { costs }\end{array}$ & \\
\hline $\begin{array}{l}\text { National } \\
\text { interest }\end{array}$ & & & & $\begin{array}{c}\text { damaging insti- } \\
\text { tutional trust }\end{array}$ \\
\hline
\end{tabular}

Source: author's own elaboration.

Table 2 is based on two dimensions. The first is the evolution of management forms. The other is the stages of risk management. Both dimensions are debatable. Jolanta Bieńkowska and Czesław Sikorski (2016) concentrate on the organizational space. There is a period of the nineteenth century - the dictate of the structure, the period of the twentieth century - the dictate of the strategy and the 21 st century - the dominance of organizational culture.

Contemporary organizational culture is based on the Internet, internationalization of production and providing services at a distance, without commercial presence. Initially, the IT revolution allows the construction of open production systems, then the service networks in the virtual space are created.

The admission of China to the World Trade Organization ten years ago has led to the revival of mercantilism, the measure of wealth has become the size of the surplus of the trade balance. In the wake of striving for a one-sided benefit from globalization, the temptation to abuse it, the concept of forcing the national interest in the first place appeared. 
The evolution of the forms of doing business, out of necessity presented in a brief form, indicates the complexity and dynamics of risk management. Risk culture and risk appetite are also evolving. It is an element of wider management changes (table 3 ).

Table 3. Reputation is responsible management

\begin{tabular}{|l|l|l|}
\hline \multicolumn{1}{|c|}{ Dimensions } & \multicolumn{1}{c|}{ Today's reputation } & \multicolumn{1}{c|}{ Tomorrow's reputation } \\
\hline Beneficiaries & Shareholders & Stakeholders \\
\hline Limitations & Resulting from organization & Value chain \\
\hline Sources of capital & Own, financial markets & Crowdfunding \\
\hline Production & Linear & Closed cycle \\
\hline Sales market & Global & $\begin{array}{l}\text { Returning significance of local } \\
\text { markets }\end{array}$ \\
\hline Growth & Unlimited & Eco-growth \\
\hline Reporting & Financial performance & Corporate social responsibility \\
\hline Customer communication & Vertical, one-direction & Horizontal communication 4.0 \\
\hline Leadership & Heroic & Responsible leadership \\
\hline
\end{tabular}

Source: author's own elaboration on the basis of: Seretny, 2018, p. 190.

\section{COMPREHENSIVE REPUTATIONAL RISK MANAGEMENT}

Analytically, different approaches to reputational risk management can be distinguished. Tomasz J. Dąbrowski (2016) identified two approaches: symbolic and substantive. The author of the study added two further approaches: active and comprehensive. The complete typology of approaches to managing reputational risk is presented in table 4 .

Table 4. Management models of reputation damage risk

\begin{tabular}{|l|c|c|c|c|}
\hline \multicolumn{1}{|c|}{ Model } & $\begin{array}{c}\text { Seeking } \\
\text { reputation }\end{array}$ & $\begin{array}{c}\text { Reputation } \\
\text { damage } \\
\text { compensation }\end{array}$ & $\begin{array}{c}\text { Active risk } \\
\text { management }\end{array}$ & $\begin{array}{c}\text { Comperehensive } \\
\text { reputational risk } \\
\text { management }\end{array}$ \\
\hline Recognition & $\mathrm{X}$ & $\mathrm{X}$ & $\mathrm{X}$ & \\
\hline Assessment & & & & $\mathrm{X}$ \\
\hline Operational & & & & \\
\hline $\begin{array}{l}\text { Learning } \\
\text { (interface) }\end{array}$ & & & & \\
\hline
\end{tabular}

Source: author's own elaboration. 
A more elaborate description of specific reputational risk management models is provided in subsequent sections of the study.

\section{Recognitive model of reputational risk management}

Reputation is an abstract concept defined by the expectations and perceptions of stakeholders. Organizations that deal with reputation only during the crisis, lose the ability to limit its damage and control negative consequences of this type of events.

The full reputational risk management cycle consists of:

- reputation indicators system,

- external audit of reputational risk,

- measuring the gap between reputation, moral hazard and trust,

- strategy for building and maintaining reputation,

- planning actions in the event of a reputation crisis,

- reputational risk management should be included in the overall risk management system in the company.

\section{Evaluation model of reputational risk management}

The core of the evaluation model of reputational risk management is the tradition of the Bank of England of matching the key positions in the banking sector to people who are 'fit and proper', ensuring sound and prudent management and therefore competent and enjoying an excellent reputation. At the same time, these features also include family members of persons appointed for managerial positions. The assessment of potential decision-makers should include the potential conflict of interest of these people, their ability to devote sufficient time, ability to perform their duties independently, without yielding.

Positive evaluation cannot be obtained by a person:

- against which the criminal proceedings before the court are conducted or when the person was convicted of a crime in the first or last instance,

- who was or is being investigated or an enforcement proceeding or an administrative sanction was imposed in connection with a violation of the statutory or executive provisions on financial services (EBC, 2016). 
Reputation evaluation may be open or closed to third parties and discretionary or factual. Table 5 shows the result of a comparison of reputation evaluation systems.

Table 5. Comparison of evaluation reputation systems

\begin{tabular}{|l|l|l|}
\hline Systems & \multicolumn{1}{|c|}{ Factual } & \multicolumn{1}{c|}{ Discretionary } \\
\hline Closed & $\begin{array}{l}\text { - register of convicts } \\
- \text { quantitative creditworthiness } \\
\text { ratings }\end{array}$ & - commercial rankings \\
\hline Open & $\begin{array}{l}\text { - internet platforms } \\
- \text { whisper advertising }\end{array}$ & $\begin{array}{l}\text { - price comparison engines } \\
- \text { social media }\end{array}$ \\
\hline
\end{tabular}

Source: own elaboration based on: Blakstad \& Allen, 2018, p. 320.

\section{Operational model of reputational risk management}

The term reputational risk management has appeared in the reports of joint-stock companies relatively recently, although the use of this term increases the value of a given joint-stock company (Heidinger \& Gatzert, 2018, p. 4).

The multidimensionality of stakeholders' expectations makes it difficult to incorporate reputational risk management into a unified enterprise risk management system. See table 6.

Table 6. Expectations of stakeholders towards operational reputational risk management

\begin{tabular}{|l|l|l|}
\hline \multicolumn{1}{|c|}{ Stakeholders } & \multicolumn{1}{|c|}{ Expectations } & \multicolumn{1}{c|}{ Image } \\
\hline Employees & $\begin{array}{l}\text { - gaining trust } \\
\text { - supporting behaviors } \\
\text { - pride from the employer }\end{array}$ & - trustworthy \\
\hline Investors & $\begin{array}{l}\text { - effectiveness of activities } \\
\text { - stability } \\
- \text { developmental potential }\end{array}$ & - credible \\
\hline Consumers & $\begin{array}{l}\text { - improving the quality of } \\
\text { products }\end{array}$ & - maintaining good standards \\
\hline Society & $\begin{array}{l}\text { - work for society } \\
\text { - caring for the natural } \\
- \text { environment }\end{array}$ & - responsible \\
\hline
\end{tabular}

Source: own elaboration based on: Krzakiewicz \& Cyfert, 2015, p. 13. 


\section{Comprehensive model of reputational risk management}

The comprehensive reputational risk management model consists of:

- a clear and communicative vision, mission and strategy of the organization,

- precise good practices practically delimiting ethical from unethical behavior,

- entering into a production or service network cultivating recognized values,

- good quality risk culture and well-known risk appetite,

- organizational culture that gives a reference point to the expectations of stakeholders,

- transparency of communication between stakeholders,

- professional crisis management (Larkin, 2003).

Reputation is a kind of social interface between stakeholders, differing in cognitive competence and access to necessary information. Excessive and lacking information and competence lead to loss of reputation. A good reputation assumes a balance between the demand for specialized information and the supply of this information (Shuttleworth, 2009).

Reputational risk management should not be considered in a 'silo' approach, in isolation from time and space. It is a process consisting of three phases: reputation (certainty), moral hazard (risk) and institutional trust (uncertainty). The organic nature of this triad causes that reputation risk management is extremely complex and dynamic.

The author's contribution is to turn attention to the costs associated with reputational risk management: internal, transactional and external. Only the joint consideration of these three types of costs allows for proper assessment of the reputation management in modern virtual organizations.

The starting point for reputational risk management is to reduce the gap between the symbolic and substantive recognition of reputation. The gap between the image and the organizational reality generates a reputation crisis.

Excessive expectations deepen the reputation crisis. Success brings strength to challenge it. Overly awakened expectations of stakeholders sooner or later lead to the loss of good reputation. Business failures often result from overly ambitious development plans. Not always the loss of reputation results from finding a skeleton in the closet. Very often it is the result of the lack of coordination of marketing activities 
with the provision of services in practice. The lack of a reputational risk management integration with a single risk management system is a good example of this type of reprehensible practices.

\section{CONCLUSIONS}

The article is of conceptual nature. It breaks with the current practice of considering reputational damage crisis management separately from decision-making infrastructure in the operational risk management process. An integral part of reputational risk management are the costs: internal, transactional, external and their distribution in the past, present and future.

Reputation from the past turns into the moral hazard today and trust in the future. Reputation management is therefore interdisciplinary and requires the competence of broadly understood social sciences. Accent on the cognitive problems of reputation and management is a novelty in the study of managing the construction and loss of reputation.

\section{REFERENCES}

Belenzon, S., Chatterji, A. \& Daley, B. (2018). Choosing between Growth and Glory. Cambridge (Mass.): National Bureau of Economic Research 24901.

Berent, T. (2013). Ogólna teoria dźwigni finansowej. Warszawa: SGH.

Bieńkowska, J. \& Sikorski, C. (2016). Ewolucja zarzqdzania. Dyktat struktury, strategii i kultury. Łódź: Wyd. Uniwersytetu Łódzkiego.

Blakstad, S. \& Allen, R. (2018). Fintech Revolution. Universal Inculusion in the New Financial Ecosystem. London: Palgrave Macmillan.

Dąbrowski, T.J. (2016). Kształtowanie reputacji banku komercyjnego. Podejście symboliczne $i$ substancjonalne. Warszawa: SGH.

Dylag, A. \& Jedynak, P. (2016). Resources and reputation in the management of universities. Jagiellonian Journal of Management, 2(1), 35-44.

EBC (2016). Decyzja EBC w sprawie oceny spetniania wymogów dotyczacych kompetencji i reputacji, nr 42, https://www.ecb.europa.eu/ecb/legal/pdf/ celex_32017d004201-pl (aceesed: 2nd April 2018).

Fukuyama, F. (1997). Zaufanie. Kapitat społeczny a droga do dobrobytu. Tłum. A. Śliwa, L. Śliwa. Warszawa: WN PWN. 
Gospodarowicz, A. (red.) (2018). Bankowość elektroniczna. Istota i innowacje. Warszawa: C.H. Beck.

Heidinger, D. \& Gatzert, N. (2018). Awareness, Determinants and Value of Reputational Risk Management: Empirical Evidence from the Banking and Insurance Industry. Erlangen-Nuernberg: Friedrich-Alexander University.

Hwang, I.D. (2017). Which Type of Trust Matters? Interpersonala vs. Institutional vs. Political Trust [Bank of Korea, Working Paper No. 15].

Jedynak, P. (2018). Znormalizowane systemy zarzadzania a ryzyko dziatalności organizacji. Kraków: Wyd. Uniwersytetu Jagiellońskiego.

Joesang, A., Ismail, R. \& Boyd, C. (2007). A survey of trust and reputation system for online service provision. Decision Support Systems, 43(2), 618-644.

Krzakiewicz, K. \& Cyfert, S. (2015). Organizational reputational risk management as a component of dynamic capabilities management process. Management, 19(1), 6-18.

Larkin, J. (2003). Strategic Reputation Risk Management. London: Palgrave Macmillan.

Linciano, N. \& Soccorso, P. (eds.) (2017). Challenges in Ensuring Financial Competencies (2017). CONSOB Working Paper No. 84.

Liu, M., Brynjolfsson, E. \& Dowlatabadi, J. (2018). Do Digital Platforms Reduce Moral Hazard? The Case of Uber and Yaxis [NBER, Working Paper No. 25015].

Miklaszewska, E. (2018). Zmiany strategiczne na europejskim rynku bankowym w okresie pokryzysowym. Warszawa: Poltext.

Paliszkiewicz, J. (2013). Zaufanie w zarzqdzaniu. Warszawa: WN PWN.

Pawłowicz, L. (2018). Moral hazard w pośrednictwie finansowym. Warszawa: Wyd. Wydziału Zarządzania Uniwersytetu Warszawskiego.

Seretny, M. (2018). Co dalej z odpowiedzialnym zarządzaniem? In: G. Gierszewska (red.). Co dalej z zarzadzaniem? (pp. 171-194). Warszawa: Oficyna Wydawnicza Politechniki Warszawskiej.

Shuttleworth, C.C. (2009). Towards a Financial Literacy Model as a Coordinanting Interface between Financial Information and Decision Makers. Pretoria: University of Pretoria.

Thakor, R.T. \& Merton, R.C. (2018). Trust in Lending [National Bureau of Economic Research, Working Paper No. 24778]. 